\title{
Pemberdayaan kelompok tani melalui pembuatan bioenergi pertanian dari limbah batang pisang
}

\author{
Nurhamidah *, Rina Elvia, Dewi Handayani, Nadia Amida, Citra Dwi Palenti \\ Universitas Bengkulu. Jl WR. Supratman, Kandang Limun, Bengkulu, 38371 Indonesia \\ ${ }^{*}$ Corresponding author email: nurhamidah@unib.ac.id
}

Received: 17 October 2020; Revised: 8 November 2020; Accepted: 12 November 2020

\begin{abstract}
Abstrak: Kabupaten Kepahiang merupakan sentra produksi sayur-sayuran dan buah-buahan salah satunya buah pisang. Kualitas produksi sangat bergantung pada proses pemeliharaan dan pemupukan yang harganya sangat memberatkan dan menjadi permasalahan bagi petani. Pasca panen, batang pisang akan dibiarkan sebagai limbah padahal batang pisang berpotensi sebagai bioenergi pertanian. Berkaitan dengan permasalahan dan potensi tersebut maka dilaksanakan kegiatan pengabdian yang bertujuan untuk memberikan pengetahuan dan motivasi kepada masyarakat Desa Tapak Gedung Kecamatan Tebat Karai Kabupaten Kepahiang Propinsi Bengkulu dalam memanfaatkan limbah pisang. Kegiatan ini dilakukan dengan menggunakan Metode Participatory Action Research (PAR) melalui 3 strategi yaitu Sosialisasi, Pelaksanaan serta monitoring dan evaluasi program. Data dikumpulkan melalui teknik observasi, Focused Group Discussion (FGD), wawancara, praktek lapangan dan dokumentasi. Kegiatan ini disambut baik dan antusias oleh masyarakat Desa Tapak Gedung. Masyarakat merasa sangat terbantu dalam penyedian pupuk organik dalam menunjang usaha pertaniannya. Berdasarkan strategi yang dilakukan dapat disimpulkan bahwa kegiatan pemberdayaan kelompok tani melalui pembuatan bioenergi pertanian dari limbah batang pisang dapat memberikan ilmu yang sangat membantu bagi masyarakat serta pembuatan pupuk organik dalam skala besar dapat dijadikan alternatife untuk peningkatan ekonomi masyarakat.
\end{abstract}

Kata Kunci: Pemberdayaan,Kelompok Tani, Bioenergi pertanian, Limbah Batang Pisang.

Abstract: Kepahiang Regency is a center for the production of vegetables and fruits, one of which is bananas. The quality of production is very dependent on the maintenance and fertilization process, which is very expensive and a problem for farmers. After harvest, banana stems will be left as waste, even though banana stems have the potential as agricultural bioenergy. In connection with these problems and potential, community service activities were carried out aimed at providing knowledge and motivation to the people of Tapak Gedung Village, Tebat Karai District, Kepahiang Regency, Bengkulu Province in utilizing banana waste. This activity is carried out using the Participatory Action Research (PAR) method through 3 strategies: socialization, implementation, and monitoring and evaluation of the program. Data were collected through observation techniques, Focused Group Discussion (FGD), interviews, field practice and documentation. This activity was welcomed and enthusiastically by the people of Tapak Gedung Village. The community feels very helpful in providing organic fertilizers to support their agricultural business. Based on the strategy carried out, it can be concluded that the activities of empowering farmer groups through the manufacture of agrarian bioenergy from banana stem waste can provide knowledge that is very helpful for the community, and the manufacture of organic fertilizers on a large scale can be used as an alternative to improve the community's economy.

Keywords: empowerment, Farmer Groups, Agricultural Bioenergy, Banana Stem Waste.

How to Cite: Nurhamidah, N., Elvia, R., Handayani, D., Amida, N., \& Palenti, C. (2020). Pemberdayaan kelompok tani melalui pembuatan bioenergi pertanian dari limbah batang pisang. JPPM (Jurnal Pendidikan dan Pemberdayaan Masyarakat), 7(2), 190-196. doi:https://doi.org/10.21831/jppm.v7i2.35136 
JPPM (Jurnal Pendidikan dan Pemberdayaan Masyarakat), 7 (2), 2020 - 191

Nurhamidah, Rina Elvia, Dewi Handayani, Nadia Amida, Citra Dwi Palenti

\section{PENDAHULUAN}

Kabupaten Kepahiang Provinsi Bengkulu merupakan salah satu daerah penghasil sayur dan buah terbesar di Provinsi Bengkulu. Sebahagian besar masyarakat sekitar daerah ini memiliki mata pencaharian dari bertani dan berkebun, diantaranya bercocok tanam kopi, lada dan juga berbagai jenis buah-buahan lokal seperti pisang, pepaya dan lainnya.

Desa Tapak Gedung merupakan salah satu desa di Kabupaten Kepahiang yang mayoritas penduduknya bertani. Desa tapak Gedung ini dipimpin oleh Kepala Desa Bapak Sutarwijaya dan sekretaris Desa Bapak Sudirman. Desa ini dihuni oleh masyarakat Suku Serawai yang berasal dari Bengkulu Selatan dan Seluma dengan mata pencaharian penduduknya bertani, seperti sayur-sayuran dan buah-buahan diantaranya tanaman pisang.

Pisang merupakan tanaman asli daerah Asia Tenggara. Tanaman dari suku Musaceae ini memiliki nama latin Musa paradisiaca. Tanaman pisang merupakan tanaman yang serba guna, mulai dari akar sampai daun dapat dimanfaatkan. Seperti negara Asia Tenggara lainnya, tanaman ini banyak ditemukan di Indonesia, terutama di daerah yang banyak mendapat sinar matahari. Budidaya tanaman pisang sesuai dengan iklim Indonesia baik dataran rendah maupun tinggi sampai dengan $1300 \mathrm{dpl}$, dan optimal pada suhu 18 - 270C, dan secara teknis mudah dibudidayakan. Produksi pisang adalah produksi buah terbesar di Indonesia yaitu $40 \%$ dari produksi buah nasional.

Limbah merupakan bahan yang terbuang atau dibuang dari suatu aktivitas manusia atau proses alam yang tidak atau belum mempunyai nilai ekonomi dan berdampak negatif pada lingkungan (Latifah et al., 2012). Beberapa contoh limbah yang sudah dimanfaatkan sebagai pupuk organik diantaranya: Limbah pertanian dan peternakan sangat baik dijadikan pupuk kompos yang sangat dibutuhkan oleh tanaman (Nurman et al., 2019; Sutanto, 2002), sedangkan (Herdiana, 2019), memanfaatkan limbah sekam padi dan jerami untuk membuat pupuk organik cair sebagai peluang usaha baru di Desa Bonder Praya Barat NTB. (Jalaluddin et al., 2017) memanfaatkan sampah buah-buahan sebagai pupuk organik. (Wijayanti et al., 2019), juga telah memanfaatkan limbah seperti air kelapa, cangkang telur dll untuk membuat nutrisi tanaman dan pupuk cair di Desa Piyungan. Salah satu limbah yang dihasilkan berasal dari perkebunan pisang. Tanaman pisang merupakan tanaman yang memiliki banyak manfaat bagi manusia, baik dari segi buah, jantung pisang serta daun yang telah dikembangkan dalam berbagai produk makanan ataupun pembungkus makanan. Namun, di sisi lain belum banyak orang yang memanfaatkan batang pisang, sehingga setelah buahnya dipanen akan meninggalkan batang pisang sebagai limbah tanpa ada pengolahan lebih lanjut. Sementara itu, menurut studi literatur, batang pisang merupakan salah satu bahan organik yang mengandung unsur-unsur penting yang dibutuhkan tanaman seperti Nitrogen $(\mathrm{N})$, Fosfor $(\mathrm{P})$ dan Kalium (K) sehingga dapat dikembangkan menjadi pupuk organik padat ataupun cair (Agustina, 2015; Astawan, 2008; Matenggomena, 2013; Roidah, 2013).

Peningkatan nilai ekonomis dari limbah batang pisang dapat dilakukan melalui pengolahan limbah batang pisang dengan bantuan bakteri EM-4 (effective microorganism-4) yang merupakan penggabungan dari empat bakteri bermanfaat yaitu Lactobacillus, Sacharomyces, Aceto-bacter dan Bacillus. Dengan bantuan EM-4 ini, limbah akan diproses secara anaerob melalui proses fermentasi sehingga menghasilkan pupuk organik dalam bentuk padat dan cair (Gunawan et al., 2015; Munawar, 2003; Nur et al., 2016).

Dengan adanya nilai ekonomis pada limbah pisang ini dapat menjadi salah satu alternative memberdayakan masyarakat dengan pemanfataan limbah pisang, dampak pemberdayaan masyarakat dengan limbah juga sudah dilakukan dalam penelitian Harahap (2018). Pada penelitian tersebut menghasilkan dampak ekonomi berkaitan pada penghematan energy yang dirasakan masyarakat dengan pemanfaatan biogas. Dikarenakan bahan baku dari biogas adalah limbah sapi yang dimanfaatkan dalam pemberdayaan begitu juga dalam kegiatan pemberdayaan ini yang memanfaatkan limbah pisang sebagai objek pemberdayaan. 
JPPM (Jurnal Pendidikan dan Pemberdayaan Masyarakat), 7 (2), 2020 - 192

Nurhamidah, Rina Elvia, Dewi Handayani, Nadia Amida, Citra Dwi Palenti

Hasil wawancara awal dengan masyarakat kelompok tani Desa Tapak Gedung, menunjukkan bahwa pada dasarnya petani memerlukan pupuk dengan harga murah untuk merangsang pertumbuhan buah dan sayur yang mereka tanam. Di samping itu tingginya produksi buah dan sayur pada daerah mereka juga menghasilkan limbah yang cukup melimpah namun belum termanfaatkan dengan baik, salah satunya batang pisang. Limbah batang pisang yang banyak tersebut dapat terlihat pada sisa lahan perkebunan masyarakat sekitar.

Berdasarkan permasalahan tersebut, tim pengabdian memberikan solusi dengan mengadakan pemberdayaan masyarakat dengan sosialisasi pembuatan bioenergi pertanian atau pupuk organik cair dari limbah batang pisang kepada masyarakat kelompok tani desa Tapak Gedung Kabupaten Kepahiang

\section{METODE}

Metode yang digunakan dalam kegiatan menggunakan Metode Participatory Action Research (PAR) melalui tiga strategi yaitu Sosialisasi, Pelaksanaan serta monitoring dan evaluasi program. PAR dipilih sesuai dengan tujuan diadakan program pemberdayaan ini, karena berakar pada prinsip-prinsip inklusi yaitu desain kegiatannya melibatkan orang, proses dan hasil yang berkelanjutan (Kidwai et al., 2017).
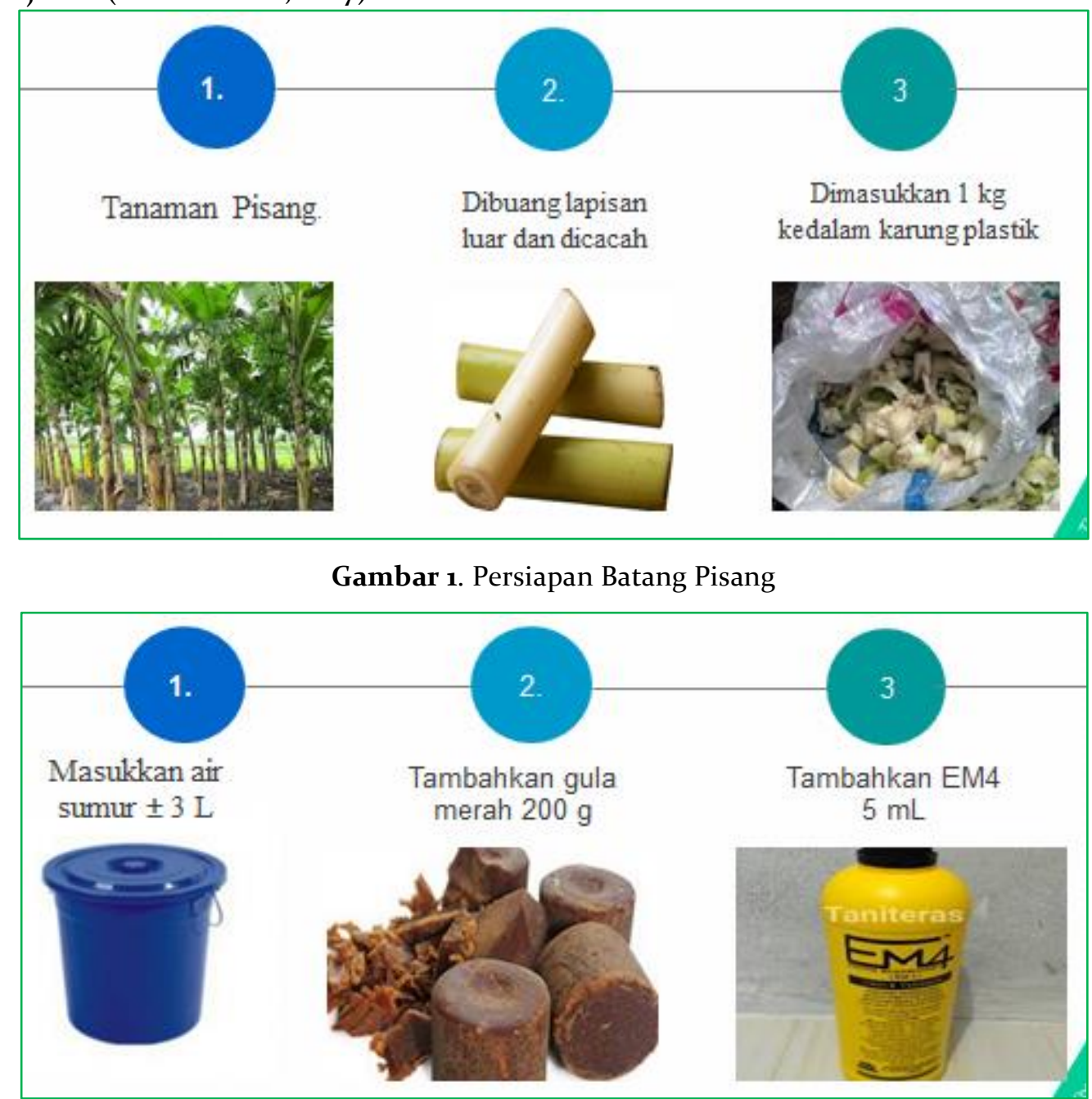

Gambar 2. Pembuatan Larutan Perendaman

Kegiatan ini diawali dengan Observasi dan wawancara untuk memperoleh gambaran permasalahan yang dihadapi oleh masyarakat dan potensi desa yang dapat dikembangkan untuk solusinya. Kegiatan selanjutnya praktel langsung pembuatan bioenergi pertanian dengan Alat dan bahan yang digunakan: ember yang pakai tutup, pisau, timbangan, karung plastik, spidol, 
JPPM (Jurnal Pendidikan dan Pemberdayaan Masyarakat), 7 (2), 2020 - 193

Nurhamidah, Rina Elvia, Dewi Handayani, Nadia Amida, Citra Dwi Palenti

kamera, batang pisang, gula merah, bioaktivator EM4 dan air tanah. Pada pelaksanaan kegiatan, tahap awalnya peserta diberikan materi serta diajak berdiskusi tentang pembuatan bioenergi pertanian atau pupuk organik serta menjelaskan tahap-tahap yang harus dilakukan untuk memanfaatkan limbah batang pisang pasca panen sebagai bahan baku pembuatan pupuk organik.

Tahap selanjutnya praktek langsung yang langkah-langkahnya seperti terlihat pada Gambar 1 dan Gambar 2 (Agustina, 2015). Pada tahap ini diberikan juga penjelasan hal-hal yang perlu dilakukan masyarakat/peserta kelompok tani selama proses fermentasi limbah batang pisang yang berlangsung (8-10 hari), sehingga produk pupuk organik yang baik bisa dihasilkan.

Langkah-langkah proses pembuatan pupuk organik, dicampur gula dengan air ke dalam ember atau tong, kemudian diaduk sampai gula larut dalam air. Potong batang pohon pisang menjadi cacahan kecill, lalu masukkan kedalam wadah karung bekas. Semakin kecil ukuran cacahan akan semakin baik, karena akan lebih mudah hancur. Masukkan karung berisi cacahan batang pohon pisang tersebut ke dalam ember atau tong berisi campuran air dan gula. Usahakan karung berisi potongan batang pohon pisang terendam seluruhnya di dalam air.

Tutup rapat tong atau ember tersebut, selanjutnya letakkan di tempat yang tidak terkena matahari langsung. Biarkan sekitar 8-10 hari, pastikan membuka tongnya sekali sehari untuk mengeluarkan gas yang terbentuk dari campuran bahan-bahan pupuk tersebut, dengan cara mengaduknya, setelah itu tutup kembali dengan rapat. Untuk mengecek tingkat kematangan, cium bau adonan, apabila wanginya seperti wangi tape berarti adonan sudah matang dan siap digunakan. Tahap selanjutnya dilakukan monitoring untuk melihat keberhasilan kegiatan.

\section{HASIL DAN PEMBAHASAN}

Pemberdayaan kepada masyarakat penerapan IPTEKS yang berjudul Pemberdayaan kelompok tani melalui pembuatan bioenergi pertanian dari limbah batang pisang di Desa Tapak Gedung Kabupaten Kepahiang telah selesai dilaksanakan. Selama peroses kegiatan, masyarakat sangat antusias dan bersemangat serta terjadi interaksi dua arah antara tim pengabdian dengan masyarakat kelompok tani yang hadir seperti yang terlihat pada gambar 3, sedangkan bioenergi pertanian berupa pupuk organik cair dan pupuk organik padat seperti yang terlihat pada gambar 4 dan 5 .
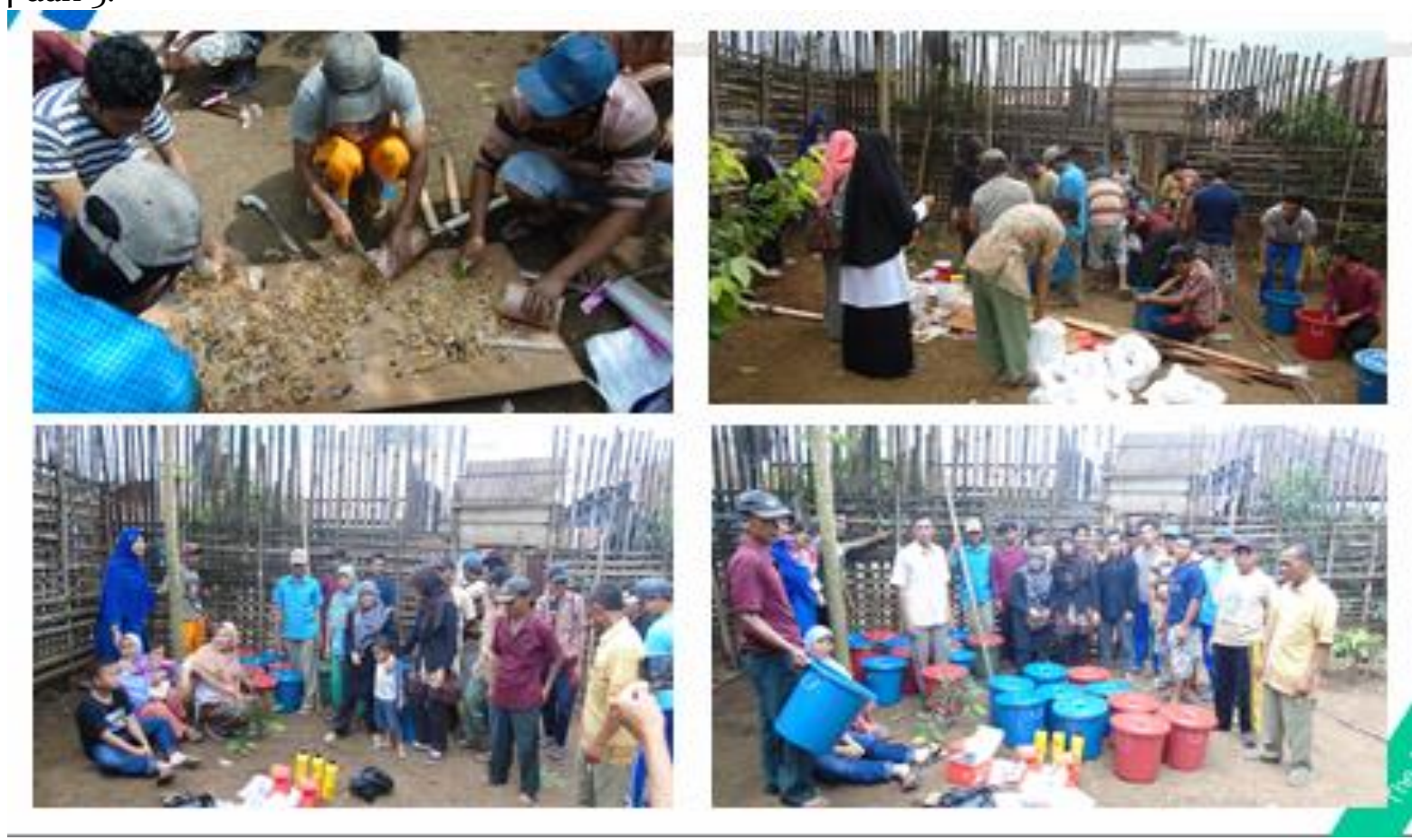

Gambar 3. Foto pada saat kegiatan 
JPPM (Jurnal Pendidikan dan Pemberdayaan Masyarakat), 7 (2), 2020 - 194

Nurhamidah, Rina Elvia, Dewi Handayani, Nadia Amida, Citra Dwi Palenti

Bioenergi pertanian ini, berupa pupuk organik cair dan pupuk organik padat seperti yang terlihat pada Gambar 4 dan Gambar 5.

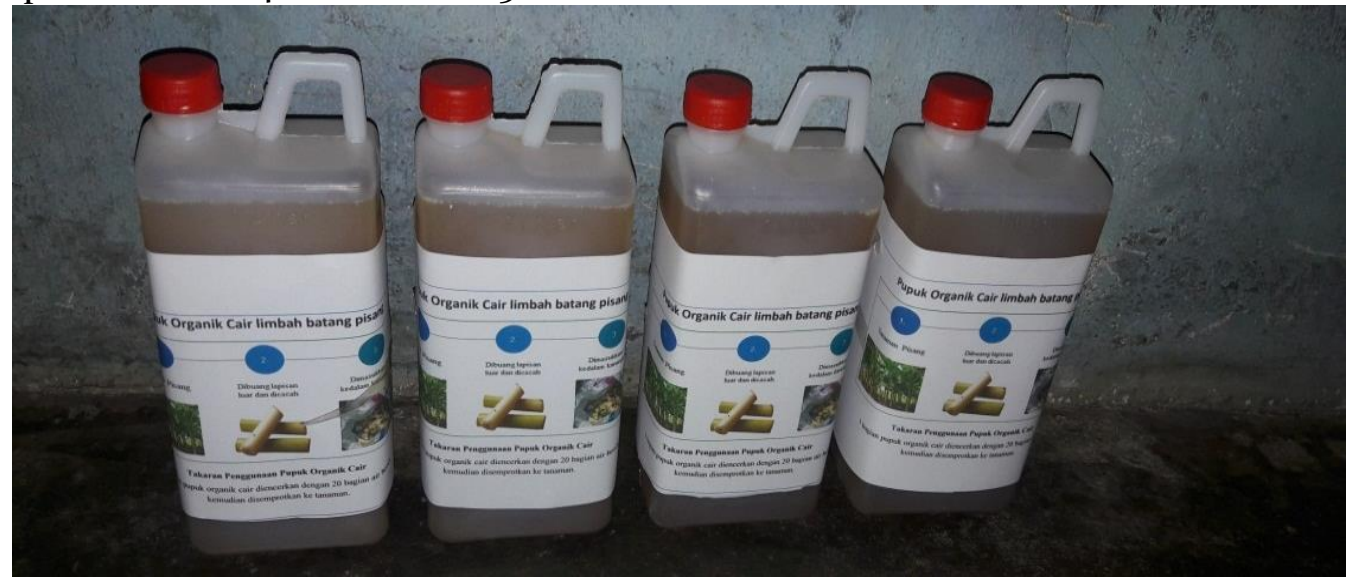

Gambar 4. Pupuk Organik Cair

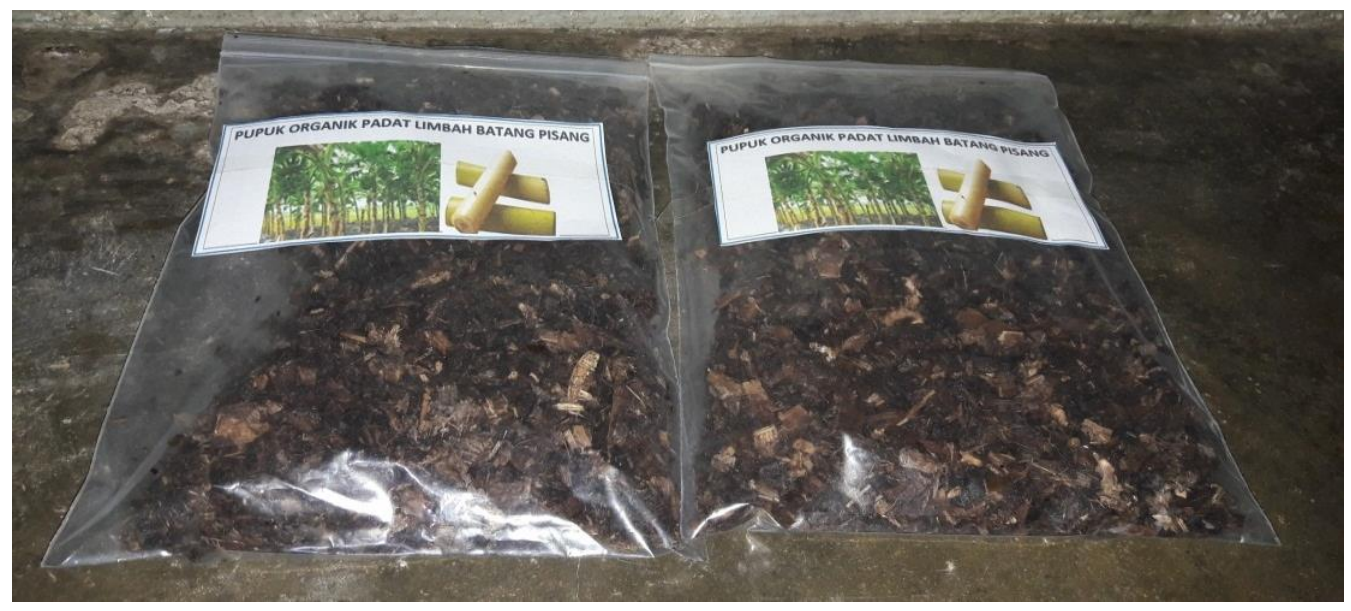

Gambar 5. Pupuk Organik Padat

Proses pembuatan Bioenergi Pertanian dilakukan oleh Tim pengabdian yang terdiri dari tiga orang dosen dan dua orang tenaga lapangan beserta perangkat desa dan kelompok tani. Kegiatan ini melibatkan dua kelompok tani yang ada di Desa Tapak Gedung, Kecamatan Tebat Karai,m Kabupaten Kepahiang, yaitu kelompok tani Serasan dan Seijon. Hasil monitoring Tim pengabdian ke beberapa warga kelompok tani, diperoleh bahwa pada umumnya bioenergi pertanian yang dibuat berhasil yang ditandai dengan timbulnya bau harum seperti tapai. Pupuk organik cair yang dihasilkan bewarna kuning kecoklatan setelah mengalami permentasi selama 1o hari, dan selanjutnya dipisahkan dengan bagian padatnya kemudian di masukkan dalam kemasan seperti botol atau tempat lainnya. Pupuk organik cair ini, dapat digunakan untuk pemupukan sayur-sayuran dan buah-buahan dengan terlebih dahulu diencerkan. Komposisi penggunaan pupuk organik cair limbah batang pisang menurut Agustina (2015) dianjurkan satu bagian pupuk cair diencerkan dengan dua puluh bagian air sumur lalu disemprotkan kebagian tanaman. Bagian padat dari hasil penyaringan pupuk organik cair tersebut dapat dimanfaatkan juga sebagai pupuk organik padat, dimana pemanfaatannya juga bisa untuk sayuran dan buahbuahan dengan cara meletakkan pupuk organik padat ini disekitar batang tanaman sayuran dan buah-buahan tersebut. Hasil monitoring dengan beberapa warga kelompok tani Desa Tapak Gedung, Kecamatan Tebat Karai, Kabupaten Kepahiang, mengatakan bahwa pupuk cair yang dihasilkan pada kegiatan pengabdian ini sudah dimanfaatkan untuk memupuk tanaman bawang dan terong, dan hasilnya bagus, dimana tanaman tersebut batangnya menjadi lebih besar dan subur. Hasil tersebut bisa dilihat pada perkebunan warga yang sudah menggunakan. Warga 
JPPM (Jurnal Pendidikan dan Pemberdayaan Masyarakat), 7 (2), 2020 - 195

Nurhamidah, Rina Elvia, Dewi Handayani, Nadia Amida, Citra Dwi Palenti

kelompok tani sangat berharap kegiatan-kegiatan seperti ini tidak berhenti, karena kegiatan ini dapat memberikan pencerahan dan sekaligus memberikan pengetahuan (knowledge) kepada masyarakat tentang pembuatan pupuk organik sederhana dari limbah batang pisang yang cukup melimpah yang belum termanfaatkan, sehingga dapat bernilai ekonomis sekaligus menunjang program pemerintah di bidang kesehatan yaitu mengurangi limbah organik sehingga lingkungan kita menjadi bersih dan sehat dan kita terhindar dari berbagai penyakit.

\section{SIMPULAN}

Dari kegiatan pengabdian ini dapat disimpulkan: (1) Masyarakat memperoleh pengetahuan (knowledge) tentang pembuatan Bioenergi pertanian atau pupuk organik secara sederhana dari limbah batang pisang yang banyak terdapat di desa Tapak Gedung ini; (2) Pupuk organik yang dihasilkan dalam skala besar dapat dijadikan alternatif untuk Meningkatkan perekonomian masyarakat; (3) Kegiatan pengabdian ini sekaligus dapat mendukung program pemerintah dari segi kesehatan dan kebersihan, karena dapat mengurangi limbah yang selama ini dibiarkan.

Kegiatan pengabdian ini sangat direspon positif oleh masyarakat Desa Tapak Gedung Kecamatan Tebat Karai Kabupaten Kepahiang, sehingga perlu juga dilakukan di desa lainnya, karena masyarakat Kabupaten Kepahiang pada umumnya bekerja di bidang pertanian yang membutuhkan pupuk yang murah dan sederhana pembuatannya

\section{DAFTAR PUSTAKA}

Agustina, T. (2015). Balai Penyuluhan Pertanian Wonomerto. $\mathrm{BKP}_{4}$ Kabupaten Probolinggo.

Astawan, M. (2008). Pisang sebagai buah kehidupan. Kompas.Com. https://money.kompas.com/read/2008/o8/17/18545832/pisang.sebagai.buah.kehidupan? page $=$ all

Gunawan, R., Kusmiadi, R., \& Prasetiyono, E. (2015). Studi pemanfaatan sampah organik sayuran sawi (Brassica juncea L.) dan limbah rajungan (Portunus pelagicus) untuk pembuatan kompos organik cair. Enviagro: Jurnal Pertanian Dan Lingkungan, 8(1), 37-47. https://www.journal.ubb.ac.id/enviagro/article/view/317

Harahap, F. I. N. (2018). Dampak pemberdayaan masyarakat melalui program biogas dalam mewujudkan kemandirian energi. JPPM (Jurnal Pendidikan Dan Pemberdayaan Masyarakat), 5(1), 41-50. https://doi.org/10.21831/jppm.v5i1.18634

Herdiana, H. (2019). Pemanfaatan limbah sekam padi dan jerami sebagai pupuk organik cair (POC) sebagai peluang usaha baru di Desa Bonder Kecamatan Praya Barat, NTB.

JURNAL AVESINA, 13(2). https://ejournal.unizar.ac.id/index.php/avesina/article/view/204

Jalaluddin, J., Nasrul, Z. A., \& Syafrina, R. (2017). Pengolahan sampah organik buah-buahan menjadi pupuk dengan menggunakan effektive mikroorganisme. Jurnal Teknologi Kimia Unimal, 5(1), 17-29. https://doi.org/10.29103/jtku.v5i1.76

Kidwai, H., Iyengar, R., Witenstein, M. A., Byker, E. J., \& Setty, R. (2017). Participatory action research and educational development: South Asian perspectives. Springer.

Latifah, R. N., Winarsih, W., \& Rahayu, Y. S. (2012). Pemanfaatan sampah organik sebagai bahan pupuk cair untuk pertumbuhan tanaman bayam merah (Alternanthera ficoides). LenteraBio: Berkala Ilmiah Biologi, 1(3), 139-144. https://jurnalmahasiswa.unesa.ac.id/index.php/lenterabio/article/view/416

Matenggomena, M. F. (2013). Pemanfaatan sampah rumah tangga untuk budidaya tanaman sayuran organik di pekarangan rumah. SinarTani-Agroinovasi, 17(3503), 17-23. https://www.litbang.pertanian.go.id/download/374/

Munawar, E. I. (2003). Pupuk organik, cair dan padat, pembuatan dan aplikasi. Penebar Swadaya. 
JPPM (Jurnal Pendidikan dan Pemberdayaan Masyarakat), 7 (2), 2020 - 196 Nurhamidah, Rina Elvia, Dewi Handayani, Nadia Amida, Citra Dwi Palenti

Nur, T., Noor, A. R., \& Elma, M. (2016). Pembuatan pupuk organik cair dari sampah organik rumah tangga dengan bioaktivator $\mathrm{EM}_{4}$ (Effective microorganisms). Konversi, 5(2), 4451. http://konversi.ulm.ac.id/index.php/konversi/article/view/6o

Nurman, S., Ermaya, D., Hidayat, F., \& Sunartaty, R. (2019). Pemanfaatan limbah pertanian dan peternakan sebagai pupuk kompos. JPPM (Jurnal Pengabdian Dan Pemberdayaan Masyarakat), 3(1), 5-8. https://doi.org/10.30595/jppm.v3i1.2709

Roidah, I. S. (2013). Manfaat penggunaan pupuk organik untuk kesuburan tanah. Jurnal Bonorowo, 1(1), 30-43. https://doi.org/10.36563/bonorowo.vili.5

Sutanto, R. (2002). Penerapan pertanian organik: Pemasyarakatan dan pengembangannya. Kanisius.

Wijayanti, A., Listiyani, L. R., Ernawati, T., \& Nurhayati, R. (2019). Merintis ketahanan pangan dan membentuk karakter peduli lingkungan pada remaja di Piyungan. JPPM (Jurnal Pendidikan Dan Pemberdayaan Masyarakat), 6(2), 111-118. 10.21831/jppm.v6i2.26656 